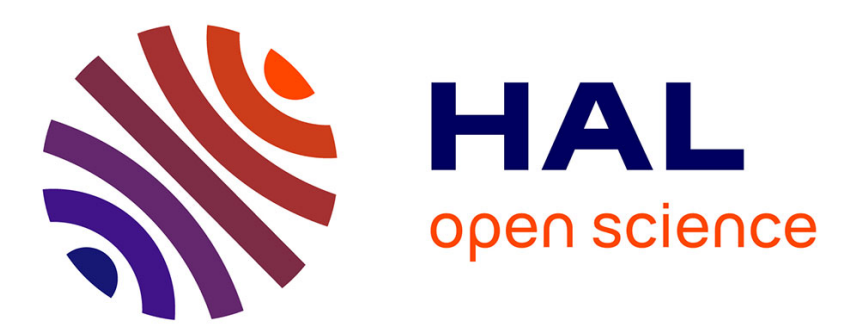

\title{
Formation of NDMA by Chloramination of Nitrogenous Pharmaceuticals
}

Julien Le Roux, H Gallard, Jean-Philippe Croué

\section{To cite this version:}

Julien Le Roux, H Gallard, Jean-Philippe Croué. Formation of NDMA by Chloramination of Nitrogenous Pharmaceuticals. Water Practice and Technology, 2010, 5 (4), http://www.iwaponline.com/wpt/005/wpt0050084.htm. 10.2166/wpt.2010.084 . hal-01201532

HAL Id: hal-01201532

https://hal-enpc.archives-ouvertes.fr/hal-01201532

Submitted on 17 Sep 2015

HAL is a multi-disciplinary open access archive for the deposit and dissemination of scientific research documents, whether they are published or not. The documents may come from teaching and research institutions in France or abroad, or from public or private research centers.
L'archive ouverte pluridisciplinaire HAL, est destinée au dépôt et à la diffusion de documents scientifiques de niveau recherche, publiés ou non, émanant des établissements d'enseignement et de recherche français ou étrangers, des laboratoires publics ou privés. 


\title{
Formation of NDMA by chloramination of nitrogenous pharmaceuticals
}

\author{
J. Le Roux*, H. Gallard*, J.P. Croué**
}

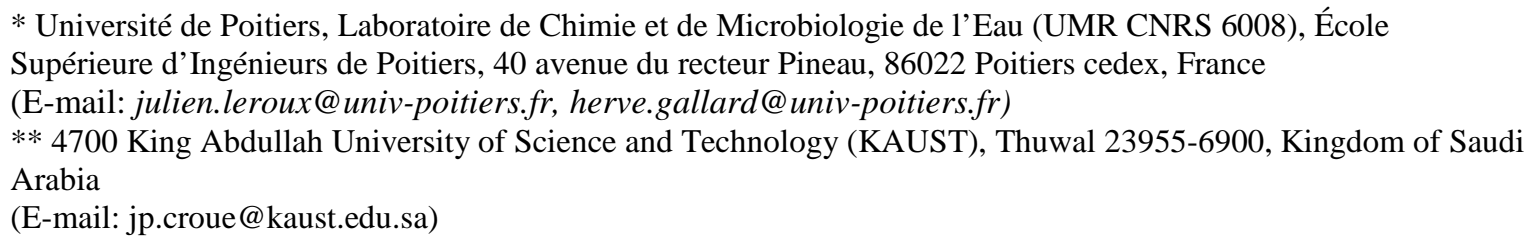

\begin{abstract}
Many disinfection by-products (DBPs) are formed during water chlorination, including trihalomethanes (THMs) and haloacetic acids (HAAs). Disinfection with chloramines is often used to reduce the production of regulated DBPs. However, chloramination can lead to the formation of $N$-nitrosamines, including $N$-nitrosodimethylamine (NDMA), a probable human carcinogen. The formation mechanisms of NDMA are not fully understood. Proposed mechanisms used dimethylamine (DMA) as a model precursor, but results show that certain widely used tertiary dimethylamines (e.g. the pharmaceutical ranitidine) show much higher conversion rates to NDMA than DMA. These amounts of NDMA cannot be explained by current proposed mechanisms. New formation mechanisms have to be proposed to explain the importance of structural characteristics of tertiary amines for NDMA formation.
\end{abstract}

Keywords

NDMA; N-nitrosodimethylamine; Chloramination; Disinfection by-products; Ranitidine

\section{INTRODUCTION}

A large diversity of disinfection by-products (DBPs) are formed during water treatment processes using chlorination, including trihalomethanes (THMs) and haloacetic acids (HAAs). Final disinfection with chloramines is known to significantly reduce the formation of regulated DBPs as compared to chlorination. However, chloramination favors the formation of $\mathrm{N}$-nitrosamines, including N-nitrosodimethylamine (NDMA). The US Environmental Protection Agency classifies NDMA as a probable human carcinogen, evaluating a $10^{-6}$ risk level of cancer from NDMA concentration at $0.7 \mathrm{ng} / \mathrm{L}$ in drinking water (EPA Integrated Risk Information System (IRIS), 1987). Over the last decade, interest has been growing about the formation mechanisms of NDMA during chloramination (Choi and Valentine, 2002; Mitch and Sedlak, 2002; Schreiber and Mitch, 2006). However those mechanisms remain partially understood. Previously proposed mechanisms are based upon a nucleophilic substitution between monochloramine $\left(\mathrm{NH}_{2} \mathrm{Cl}\right)$ and dimethylamine (DMA), forming an Unsymmetrical Dimethylhydrazine (UDMH) intermediate (Choi and Valentine, 2002; Mitch and Sedlak, 2002). UDMH is then rapidly oxidized by monochloramine to form NDMA (Scheme 1).

\section{Scheme 1}

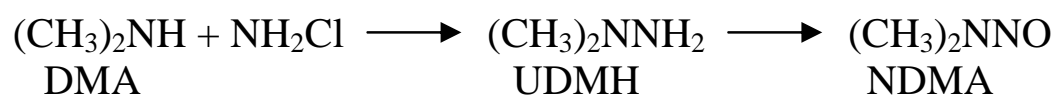

Over the past few years, studies demonstrated the importance of chloramine speciation and dissolved oxygen concentration during the formation of NDMA (Schreiber and Mitch, 2006). Dichloramine $\left(\mathrm{NHCl}_{2}\right)$ was found to lead to the formation of more NDMA from DMA than monochloramine. At $\mathrm{pH}<8$, dichloramine is the dominant species, leading to higher amounts of NDMA formed. Higher dissolved oxygen concentrations were also found to enhance the formation of NDMA. 
Reaction mechanisms have been proposed to explain the role of $\mathrm{NHCl}_{2}$ and dissolved $\mathrm{O}_{2}$. Dichloramination of DMA would form a chlorinated UDMH intermediate (UDMH-Cl) rather than $\mathrm{UDMH}$, then dissolved $\mathrm{O}_{2}$ incorporation would lead to NDMA (Scheme 2).

\section{Scheme 2}

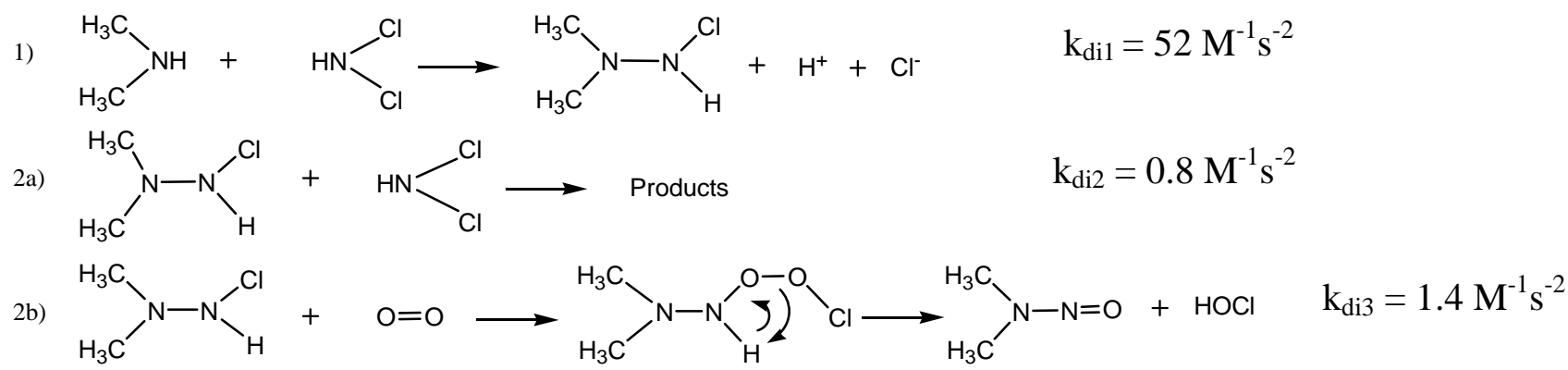

Some studies indicated that amounts of DMA present in surface waters (Gerecke and Sedlak, 2003) or secondary municipal wastewaters (Mitch and Sedlak, 2004) cannot be sufficient to explain the amount of NDMA formed after chloramination. NDMA precursors in natural organic matter (e.g. humic substances) are not fully determined. The potential importance of tertiary amines presenting dimethylamine functional groups (e.g. ranitidine, a histamine antagonist often used for peptic ulcer treatment) has been pointed (Mitch and Sedlak, 2004; Schmidt et al., 2006). Several studies demonstrated that ranitidine and other pharmaceuticals are not well removed by biological treatments and can be found in river waters receiving the WWTP effluents (Castiglioni et al., 2005; Radjenovic et al., 2009). Chloramination of natural waters impacted by pharmaceuticals is of great concern because of the potential risk of NDMA formation.

In the present work, NDMA formation potential of several nitrogen-containing organic compounds from the reaction with monochloramine is investigated. Model compounds investigated are 5 pharmaceuticals: ranitidine (peptic ulcer treatment); doxepine and amitriptyline (tricyclic antidepressants); mifepristone (an abortifacient) and minocycline (an antibiotic used for acne treatment). Two herbicides (diuron and isproturon) were also investigated to compare NDMA formation potentials of different molecular structures. All of these compounds are tertiary amines presenting DMA functional groups. These anthropic compounds are likely to enter natural waters via wastewater treatment plants (pharmaceuticals) or agricultural runoff (herbicides).

\section{MATERIALS AND METHODS}

\section{Materials}

All experiments were conducted using deionized water (Milli-Q, Millipore) buffered with a mixture of sodium phosphate monobasic and sodium phosphate dibasic. Solution $\mathrm{pH}$ values were adjusted as needed using sodium hydroxide or sulfuric acid $(0.1 \mathrm{~N}$, Fisher Scientific). Fisher Scientific methylene chloride (GLC grade) and Carlo Erba methanol $(>99.9 \%)$ were used without further purification. Amitriptyline (>98\%), doxepine (>98\%), mifepristone (>98\%), minocycline (92\%, $8 \%$ water), diuron $(>98 \%)$, isoproturon $(99.8 \%)$ and ranitidine were used without further purification and were supplied through Sigma-Aldrich. Sodium hypochlorite (NaOCl, $13 \%$, Acros Organics) and ammonium chloride (Fisher Scientific, 99.9\%) were used as chlorination reagents. Anhydrous sodium sulfite (Fisher Scientific) was used for quenching chlorine. Isotopically labeled standards, $\left[6-{ }^{2} \mathrm{H}\right] \mathrm{N}$-nitrosodimethylamine (NDMA-d6, $98 \%, 1 \mathrm{mg} \cdot \mathrm{mL}^{-1}$ in methylene chloride) and $\left[14-{ }^{2} \mathrm{H}\right] \mathrm{N}$-nitrosodi-n-propylamine (DPNA-d14, $98 \%, 1 \mathrm{mg} \cdot \mathrm{mL}^{-1}$ in methylene chloride) were obtained from Cambridge Isotope Laboratories (Andover, MA, USA). A standard solution 
containing seven $N$-nitrosamines $(2000 \mu \mathrm{g} / \mathrm{mL}$ each in methylene chloride) was purchased from Supelco (Sigma-Aldrich). The SPE materials used to extract nitrosamines from aqueous solutions consisted in Supelclean ${ }^{\mathrm{TM}}$ prepacked coconut charcoal EPA 521 tubes, $2 \mathrm{~g} / 6 \mathrm{ml}$, supplied through Supelco.

\section{Preparation and Analysis of Chloramine}

Monochloramine $\left(\mathrm{NH}_{2} \mathrm{Cl}\right)$ stock solutions were prepared fresh daily by dissolving ammonium chloride $\left(\mathrm{NH}_{4} \mathrm{Cl}\right)$ in deionized water adjusted to $\mathrm{pH}=8.5$ with sodium hydroxide. Sodium hypochlorite $(\mathrm{NaOCl})$ was then added slowly to the rapidly stirred solution, at a $\mathrm{Cl}: \mathrm{N}$ molar ratio of at least 1:1.2 to avoid breakpoint chlorination resulting from local excess of hypochlorite (Mitch and Sedlak, 2002). Adjusting the $\mathrm{pH}$ at 8.5 minimizes the disproportionation of $\mathrm{NH}_{2} \mathrm{Cl}$ to dichloramine $\left(\mathrm{NHCl}_{2}\right)$, since $\mathrm{NHCl}_{2}$ forms at $\mathrm{pH}<8$ (U.S. Environmental Protection Agency, 1999) according to the equilibrium:

$2 \mathrm{NH}_{2} \mathrm{Cl}+\mathrm{H}^{+}=\mathrm{NHCl}_{2}+\mathrm{NH}_{4}^{+}$(1)

$\mathrm{NH}_{2} \mathrm{Cl}$ and $\mathrm{NHCl}_{2}$ were distinguished and quantified in chloramine stock solutions by monitoring absorbances at their respective $\lambda_{\max }\left(\lambda_{\mathrm{NH} 2 \mathrm{Cl}}=245 \mathrm{~nm} ; \lambda_{\mathrm{NHCL} 2}=295 \mathrm{~nm}\right)$. Residual chlorine in samples after experiments was analyzed iodometrically (Standard Methods for the Examination of Water and Wastewater, 1995).

\section{Chloramination Experiments}

All glassware used during these experiments was washed and baked at $500{ }^{\circ} \mathrm{C}$ for at least $5 \mathrm{~h}$ prior to use. Reactions were conducted in sealed $1 \mathrm{~L}$ amber glass bottles at $20{ }^{\circ} \mathrm{C}$ in a temperaturecontrolled room, under dark conditions to avoid photolysis of NDMA. Chloramination experiments were conducted following the approach of Mitch et al. (Mitch et al., 2003), using high concentrations of monochloramine $\left(200\right.$ to $300 \mathrm{mg} / \mathrm{L}$ as $\left.\mathrm{Cl}_{2}\right)$ and a reaction time of 5 days at $\mathrm{pH} 8$. Aqueous solutions were prepared by dissolving a pre-determined amount of compounds investigated in $1 \mathrm{~L}$ of Milli-Q water containing $10 \mathrm{mM}$ buffer. $100 \mathrm{~mL}$ preformed monochloramine was then added. Each series of experiments included a blank (deionized water buffered and chloraminated) and samples were triplicated for each compound investigated. After 5 days contact time, $100 \mathrm{~mL}$ of samples were transferred for residual chlorine analysis and $1 \mathrm{~L}$ was processed for NDMA analysis. Molar yields were calculated based on the molar concentrations of test compounds (mol NDMA formed $\times 100 /$ mol initial compound).

\section{NDMA Analysis}

NDMA was analysed following the US EPA method (U.S. Environmental Protection Agency, 2004), which consists in a solid-phase extraction (SPE) using coconut charcoal EPA 521 tubes followed by GC/MS analysis in EI mode. Chloramination reactions were quenched using $2.5 \mathrm{~g}$ sodium sulfite before extraction. Prior to the extraction, $200 \mathrm{ng}$ of NDMA-d6 was added to each $1 \mathrm{~L}$ sample as an internal standard. Under slight vacuum, each sample was transferred to a SPE tube at a flow rate of $6 \mathrm{~mL} / \mathrm{min}$. Analytes were eluted from the SPE bed with $15 \mathrm{~mL}$ methylene chloride and collected in glass tubes. To eliminate residual water from the SPE tube, extracts were passed through a column packed with $5 \mathrm{~g}$ of anhydrous sodium sulfate and collected in glass tubes. Extracts were then concentrated under a stream of $\mathrm{N}_{2}$, and DPNA-d14 (200 ng) was added as a recovery standard. The final volume of the extract was adjusted to $1 \mathrm{~mL}$. Samples extracts were analyzed immediately after SPE using a HP 6890 series gas chromatograph system coupled with a HP 5973 mass selective detector (MSD) in electron ionization (EI) mode. Pulsed splitless injection of $1 \mu \mathrm{L}$ (25 psi during $1 \mathrm{~min})$ was used with an inlet temperature of $230{ }^{\circ} \mathrm{C}$. The carrier gas (helium) was in constant flow mode at $1 \mathrm{~mL} / \mathrm{min}$. A Varian VF-5ms capillary column (30 $\mathrm{m}$ by $0.25 \mathrm{~mm}$ i.d. by $0.25 \mu \mathrm{m}$ film thickness) supplied through Interchim was used to separate the analytes, with the following oven temperature program: initial temperature $40{ }^{\circ} \mathrm{C}$, held for 3 min; then a ramp of $4^{\circ} \mathrm{C} / \mathrm{min}$ to $110^{\circ} \mathrm{C}$; and a final ramp of $15^{\circ} \mathrm{C} / \mathrm{min}$ to $170{ }^{\circ} \mathrm{C}$ (total run time: 
$24.5 \mathrm{~min}$ ). The GC/MSD interface temperature was $280^{\circ} \mathrm{C}$, the MSD ion source and the quadrupole temperatures were $230^{\circ} \mathrm{C}$ and $150{ }^{\circ} \mathrm{C}$, respectively. Analytical data were acquired in selected-ion monitoring (SIM) mode for quantitation, using ions described in Table 1, and in full scan mode $(40-240 \mathrm{~m} / \mathrm{z})$ for additional information. This method reached extraction efficiencies of approximately $85 \%$, higher than other methods described in the literature (40 to $60 \%$ )(Choi and Valentine, 2002; Mitch and Sedlak, 2002; Schreiber and Mitch, 2006). To determine the Method Detection Limit (MDL) for each $N$-nitrosamine, 8 solutions containing $80 \mathrm{ng} / \mathrm{L} N$-nitrosamine mix and $160 \mathrm{ng} / \mathrm{L}$ NDMA-d6 were extracted and analyzed. The method detection limit (MDL) for NDMA at the $99 \%$ confidence level was determined to be $33 \mathrm{ng} / \mathrm{L}$. Standard solutions containing the $7 \mathrm{~N}$-nitrosamines at concentrations from 32 to $800 \mu \mathrm{g} / \mathrm{L}(\mathrm{n}=5)$ and the 2 deuterated standards $(200 \mu \mathrm{g} / \mathrm{L})$ were analyzed before each series of experiments (Figure 1).

Table 1. $N$-Nitrosamines analyzed by GC/MS.

\begin{tabular}{lccc}
\hline Compound & $\begin{array}{c}\text { Exact molecular } \\
\text { mass (g/mol) }\end{array}$ & $\begin{array}{c}\text { Retention time } \\
(\mathbf{m i n})\end{array}$ & $\begin{array}{c}\text { Monitoring Ions } \\
(\mathbf{m} / \mathbf{z})\end{array}$ \\
NDMA-d6 & 80.086 & 4.16 & 80 \\
NDMA & 74.048 & 4.20 & 74 \\
MENA & 88.064 & 6.64 & 88 \\
DENA & 102.07 & 9.02 & 102 \\
DPNA-d14 & 144.19 & 15.40 & $78 ; 144$ \\
NPyr & 100.06 & 15.52 & 100 \\
DPNA & 130.11 & 15.69 & $70 ; 130$ \\
Npip & 114.07 & 17.18 & 114 \\
DBNA & 158.14 & 22.20 & $84 ; 158$ \\
${ }^{a}$ Ions used for selected-ion monitoring (SIM), EI mode \\
\hline
\end{tabular}

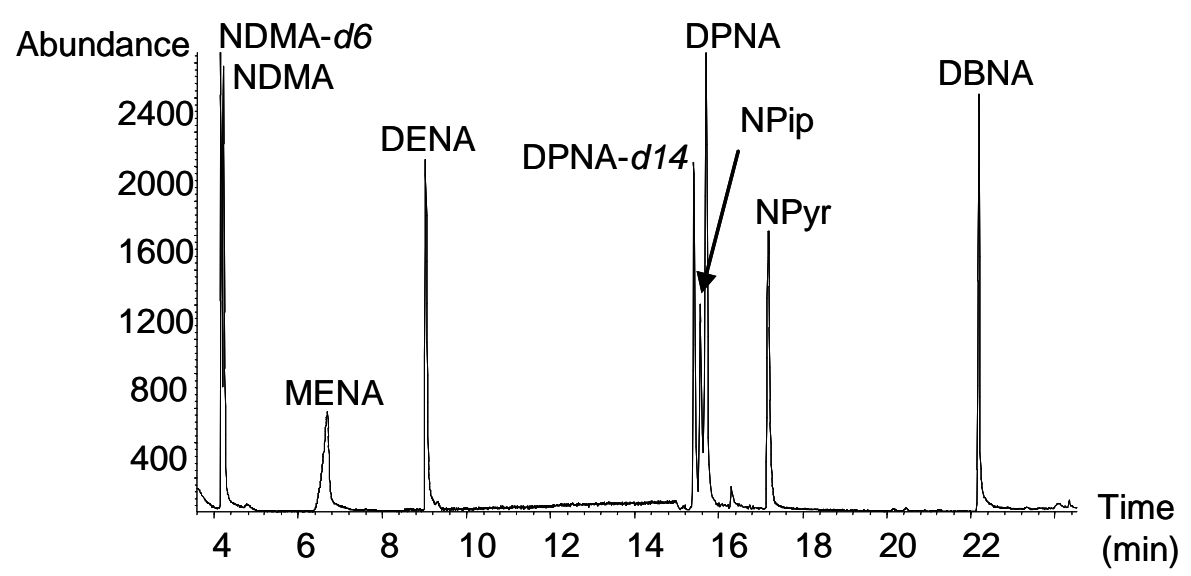

Figure 1. GC/MS chromatogram in SIM (Selected-Ion Monitoring) mode of a calibration mix $(160 \mu \mathrm{g} / \mathrm{L})$ containing $7 \mathrm{~N}$-nitrosamines and 2 deuterated internal standards.

\section{RESULTS AND DISCUSSION}

Residual chlorine concentrations were measured at the end of the contact time. Under our experiments conditions, monochloramine $\left(\mathrm{NH}_{2} \mathrm{Cl}\right)$ predominantly decays by self-disproportionation (Jafvert and Valentine, 1992). Decomposition of $\mathrm{NH}_{2} \mathrm{Cl}$ over 5 days was always about $50 \%$ for each compound investigated. Results from control samples exhibited similar chlorine decay, so $\mathrm{NH}_{2} \mathrm{Cl}$ consumption is likely to occur most by self-disproportionation. Hence, the consumption of $\mathrm{NH}_{2} \mathrm{Cl}$ by compounds investigated could not be quantified. However, $\mathrm{NH}_{2} \mathrm{Cl}$ remained in excess all over the contact time, even after a contact time of 8 days (Figure 2). NDMA formation from $3 \mu \mathrm{M}$ 
ranitidine and $2.5 \mathrm{mM} \mathrm{NH} \mathrm{NL}_{2} \mathrm{Cl}$ aH 8.5 was evaluated over 8 days (Figure 2). Results show that NDMA leveled off after $24 \mathrm{~h}$ contact time. In following results, a 5 days contact time was kept to compare our results with NDMA formation potential methods already proposed in the literature (Mitch et al., 2003).

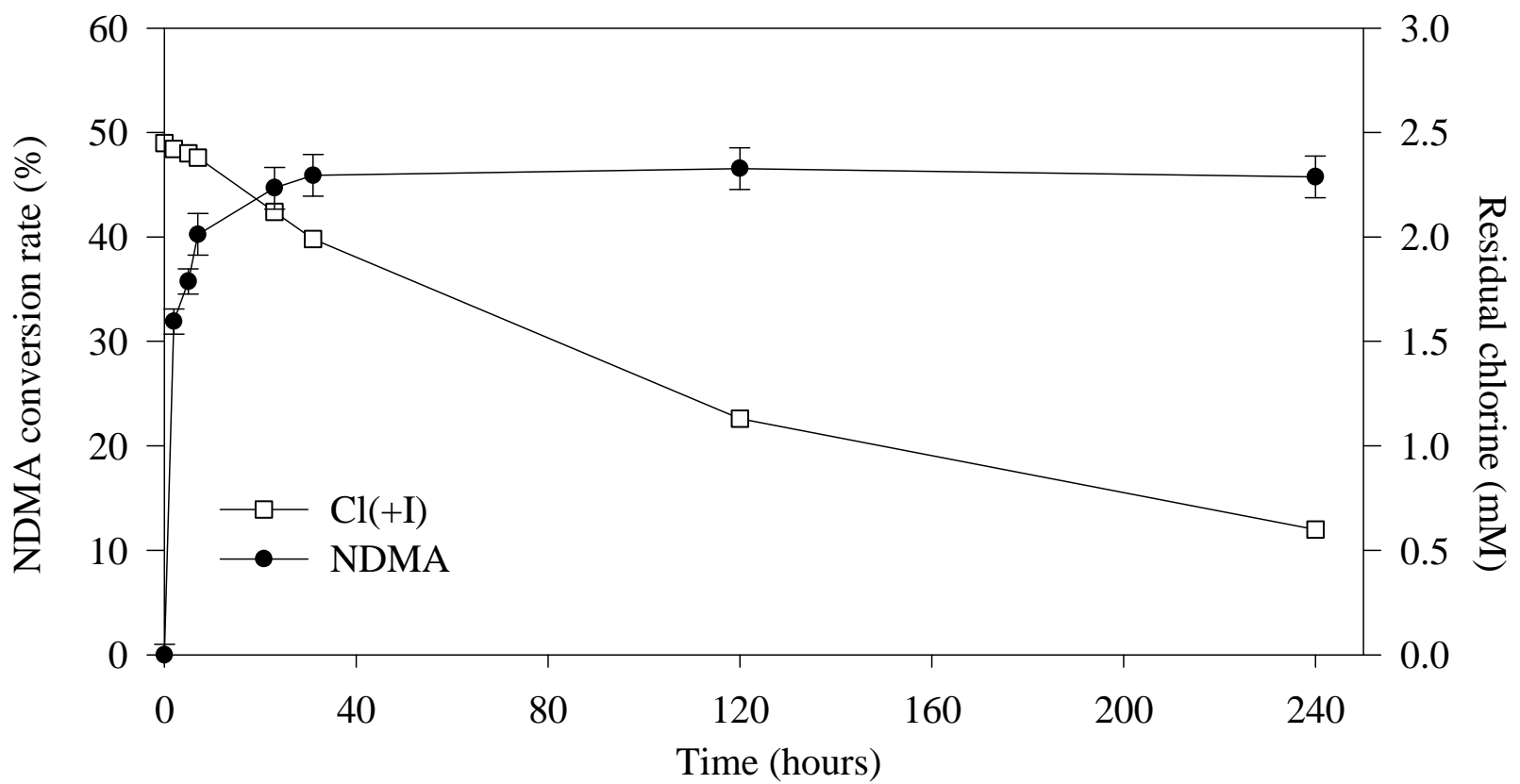

Figure 2. NDMA formation from $3 \mu \mathrm{M}$ ranitidine buffered at $\mathrm{pH} 8.5$ with $10 \mathrm{mM}$ phosphate buffer, $2.5 \mathrm{mM}$ monochloramine. Error bars represent one standard deviation $(n=3)$. NDMA molar conversion rates were calculated based upon the initial ranitidine concentration.

The formation of NDMA from selected compounds was monitored after chloramination during 5 days at $\mathrm{pH} 8.5$ with $10 \mathrm{mM}$ phosphate buffer. Ranitidine exhibited the highest molar conversion rate with 40.22\% NDMA formed (Figure 3). Conversion rates for other pharmaceuticals were in the range of 0.4 to $8.2 \%$. NDMA formation from DMA is known to be $<0.5 \%$ molar conversion (Schmidt et al., 2006; Schreiber and Mitch, 2006). In our study, pharmaceuticals minocycline, amitriptyline, doxepine and especially ranitidine exhibited higher conversion rates to NDMA than DMA. At pH 7.9 and after only $2 \mathrm{~h}$, ranitidine formed $59.63 \%$ NDMA (Data not shown), which is close to a value reported in another study (62.9\%) (Schmidt et al., 2006).

Table 2 shows molecular structures of nitrogenous compounds investigated. Minocycline contains two dimethylamine functional groups NDMA, which partially explains why it formed more NDMA than other compounds (8.21\% molar conversion). Ranitidine contains a heterocyclic ring (furan) substituted with a DMA function. This molecular structure seems to enhance the formation of NDMA compared to other aromatic rings (amitriptyline, mifepristone). Doxepine contains one oxgen atom in its center ring and forms more NDMA than amitriptyline, which is not heterocyclic. This also indicates that heterocyclic rings substituted with NDMA functions form more NDMA.

Compounds presenting aromatic rings substituted with DMA functions tend to form more NDMA than compounds with DMA functions near carbonyl groups (herbicides). Mifepristone and minocycline contains a DMA function directly linked to an aromatic ring, while amitriptyline and doxepine comprise 3 carbon atoms between the DMA function and the ring. Amitriptyline and doxepine form more NDMA than mifepristone but less than minocycline, which indicates that the length of carbon chains between rings and DMA functions does not seem to influence NDMA 
formation.

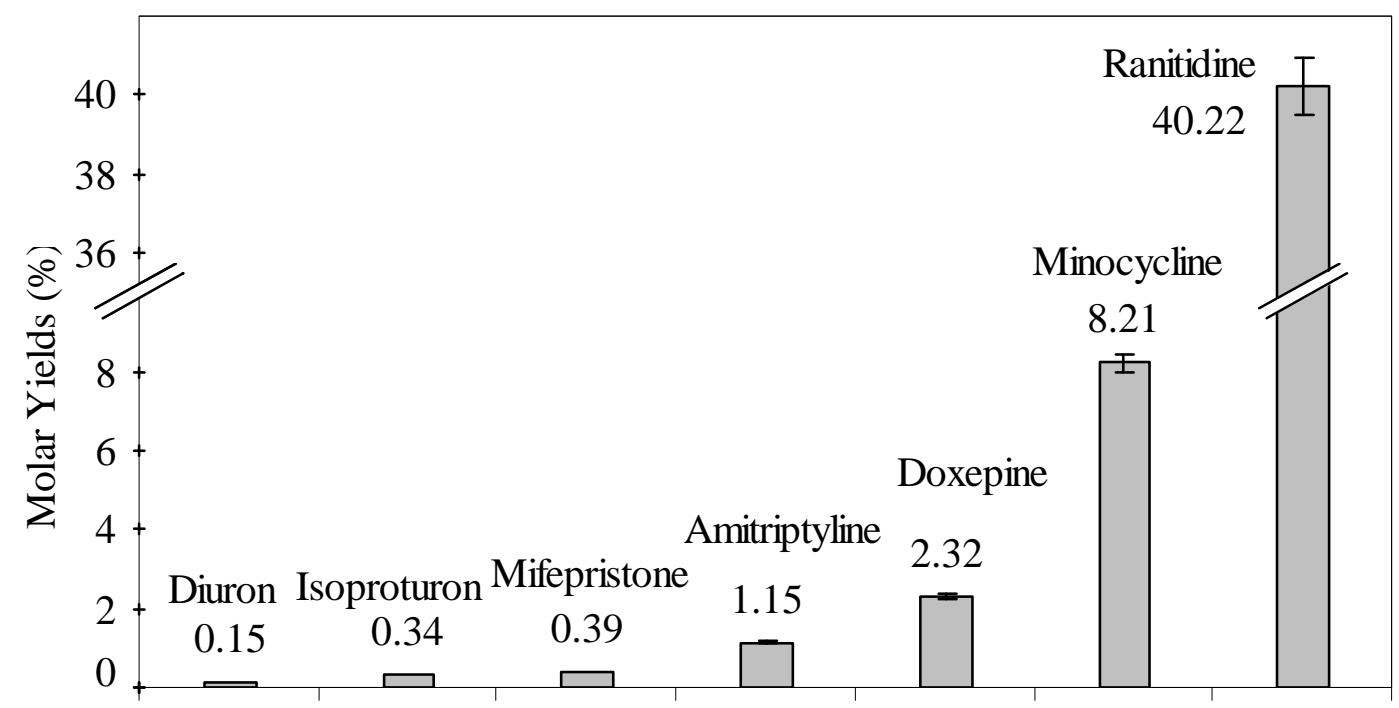

Figure 3. NDMA formation after chloramination $\left(2.5 \mathrm{mM} \mathrm{NH}_{2} \mathrm{Cl}\right)$ of nitrogenous pharmaceuticals $(3 \mu \mathrm{M})$ and herbicides at $\mathrm{pH}=8.5(10 \mathrm{mM}$ phosphate buffer $)$ and 5 days time contact. Molar yields were calculated based upon the initial pharmaceutical concentration. Error bars represent one standard deviation $(n=3)$. Note the change of scale.

Since every compounds investigated contain dimethylamine functional groups, such differences in NDMA formation can not be explained by current proposed formation mechanisms, only based on DMA as a precursor. NDMA formation from ranitidine cannot be explained by the break of the carbon-nitrogen bond between the DMA functional group and the heterocyclic ring. In that case, DMA would react with $\mathrm{NH}_{2} \mathrm{Cl}$ or $\mathrm{NHCl}_{2}$ to form NDMA at yields already observed for experiments involving DMA. Some studies proposed a formation pathway for NDMA during chlorination or chloramination of diuron (Chen and Young, 2008; Chen and Young, 2009). This pathway is based on the oxidation of diuron to form DMA and 3,4-dichloroaniline (DCA). DMA could then react with $\mathrm{NHCl}_{2}$ to directly form NDMA, or with nitrosating agents formed by the oxidation of DCA. However, our results show that NDMA formation from diuron is much lower than from other compounds. Reaction mechanisms which could explain NDMA formation from heterocyclic aromatic rings substituted with DMA functional groups remain unclear. Further research need to study simpler compounds than pharmaceuticals. Different heterocyclic rings compounds (thiophenes, pyrroles or furans substituted with DMA functions) need to be investigated to understand the role of heteroatoms or carbon chain lengths.

Table 2. Molecular structures of nitrogenous compounds investigated

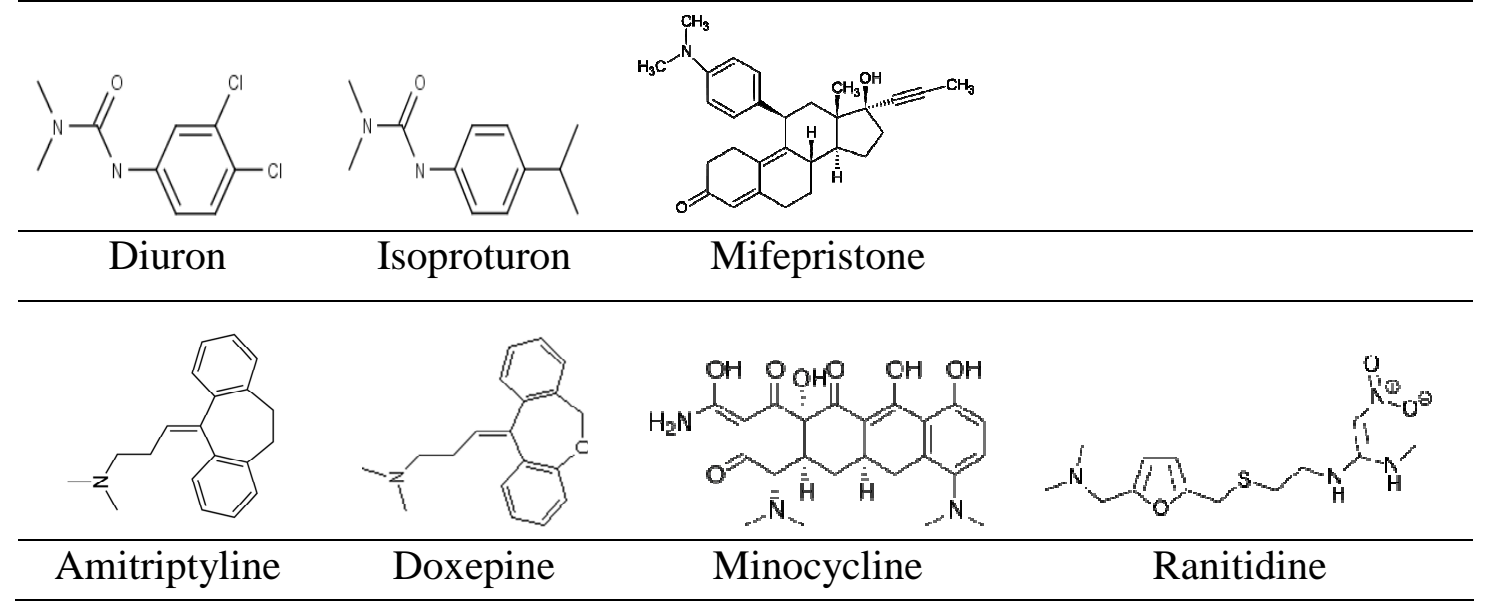




\section{CONCLUSIONS}

Even if concentrations of compounds used for our study were relatively high and are not likely to be found in natural waters, we observed that several nitrogenous anthropic compounds can lead to important concentrations of NDMA. Especially, the pharmaceutical ranitidine is of great concern regarding its high molar conversion rate into NDMA ( 60\% at $\mathrm{pH} 7.9)$. Ranitidine is sold worldwide as a gastrointestinal drug and has been detected at concentrations ranging from $70 \mathrm{ng} / \mathrm{L}$ to $540 \mathrm{ng} / \mathrm{L}$ in primary effluents of wastewater treatment plants (WWTP) in Spain (Radjenovic et al., 2009) and at $\sim 10 \mathrm{ng} / \mathrm{L}$ in several surface waters (Zuccato et al., 2000; Kolpin et al., 2002). Several studies demonstrated that ranitidine and other pharmaceuticals are not well removed by biological treatments and can be found in river waters receiving WWTP effluents (Castiglioni et al., 2005; Radjenovic et al., 2009). Considering the high conversion rate of ranitidine to NDMA, the use of chloramination as a secondary disinfection for wastewaters containing ranitidine can lead to the formation of important amounts of NDMA. This could explain the high NDMA formation potentials observed at several WWTP, which are much higher than concentrations predicted based upon DMA concentrations in raw waters and calculated following previously proposed formation mechanisms (Mitch and Sedlak, 2004; Mitch et al., 2003). Several studies demonstrated that DMA molar conversion rate into NDMA during chloramination is lower than $1 \%$ (Choi and Valentine, 2002; Schmidt et al., 2006; Schreiber and Mitch, 2006). From the seven compounds investigated in our study, four exhibited conversion rates higher than $1.15 \%$ (ranitidine, minocycline, doxepine, amitriptyline). Tertiary amines compounds containing heterocyclic or aromatic rings substituted with DMA groups form much more NDMA than DMA or tertiary amines containing carbonyl groups (diuron, isoproturon). More simple compounds (i.e. furans or thiophenes substituted with DMA functional groups) than those described in the present work need to be studied to understand the importance of structural characteristics of tertiary amines compounds for NDMA formation. The influence of chloramination conditions ( $\mathrm{pH}$, dose, contact time) and especially the role of dissolved oxygen concentration and chloramines speciation (i.e. NDMA formation from the reaction with $\mathrm{NHCl}_{2}$ ) will also be studied in further researches.

\section{REFERENCES}

Castiglioni S., Bagnati R., Fanelli R., Pomati F., Calamari D. and Zuccato E. (2005). Removal of Pharmaceuticals in Sewage Treatment Plants in Italy. Environmental Science \& Technology, 40(1), 357-363.

Chen W. and Young T.M. (2008). NDMA formation during chlorination and chloramination of aqueous diuron solutions. Environmental Science and Technology, 42(4), 1072-1077.

Chen W. and Young T.M. (2009). Influence of nitrogen source on NDMA formation during chlorination of diuron. Water Research, 43(12), 3047-3056.

Choi J. and Valentine R.L. (2002). Formation of N-nitrosodimethylamine (NDMA) from reaction of monochloramine: A new disinfection by-product. Water Research, 36(4), 817-824.

EPA Integrated Risk Information System (IRIS) (1987) N-nitrosodimethylamine. Office of Research and Development (ORD), National Center for Environmental Assessment. http://www.epa.gov/iris/subst/0045.htm (accessed October 20, 2008).

Gerecke A.C. and Sedlak D.L. (2003). Precursors of N-nitrosodimethylamine in natural waters. Environmental Science and Technology, 37(7), 1331-1336.

Jafvert C.T. and Valentine R.L. (1992). Reaction scheme for the chlorination of ammoniacal water. Environmental Science and Technology, 26(3), 577-786. 
Kolpin D.W., Furlong E.T., Meyer M.T., Thurman E.M., Zaugg S.D., Barber L.B. and Buxton H.T. (2002). Pharmaceuticals, Hormones, and Other Organic Wastewater Contaminants in U.S. Streams, 1999-2000: A National Reconnaissance. Environmental Science \& Technology, 36(6), 1202-1211.

Mitch W.A. and Sedlak D.L. (2002). Formation of N-nitrosodimethylamine (NDMA) from dimethylamine during chlorination. Environmental Science and Technology, 36(4), 588-595.

Mitch W.A. and Sedlak D.L. (2004). Characterization and Fate of N-Nitrosodimethylamine Precursors in Municipal Wastewater Treatment Plants. Environmental Science and Technology, 38(5), 1445-1454.

Mitch W.A., Gerecke A.C. and Sedlak D.L. (2003). A N-Nitrosodimethylamine (NDMA) precursor analysis for chlorination of water and wastewater. Water Research, 37(15), 3733-3741.

Radjenovic J., Petrovic M. and Barceló D. (2009). Fate and distribution of pharmaceuticals in wastewater and sewage sludge of the conventional activated sludge (CAS) and advanced membrane bioreactor (MBR) treatment. Water Research, 43(3), 831-841.

Schmidt C.K., Sacher F. and Brauch H. (2006) Strategies for minimizing formation of NDMA and other nitrosamines during disinfection of drinking water. Proceedings of the American Water Works Association Water Quality Technology Conference, Denver, CO.

Schreiber I.M. and Mitch W.A. (2006). Nitrosamine formation pathway revisited: The importance of chloramine speciation and dissolved oxygen. Environmental Science and Technology, 40(19), 6007-6014.

Standard Methods for the Examination of Water and Wastewater (1995). 19th ed.; American Public Health Association/American Water Works Association/Water Environment Federation, Washington D.C., USA.

U.S. Environmental Protection Agency (1999) Alternative disinfectants and oxidants. EPA guidance manual. http://www.epa.gov/OGWDW/mdbp/alternative_disinfectants_guidance.pdf (accessed April 10, 2009).

U.S. Environmental Protection Agency (2004) Method 521: determination of nitrosamines in drinking water by solid phase extraction and capillary column gas chromatography with large volume injection and chemical ionization tandem mass spectrometry (MS/MS). EPA/600/R-05/054. http://www.epa.gov/nerlcwww/m_521.pdf (accessed October 20, 2008).

Zuccato E., Calamari D., Natangelo M. and Fanelli R. (2000). Presence of therapeutic drugs in the environment. The Lancet, 355(9217), 1789-1790. 